\title{
Tuhan Ada di Mana-mana: Mencari Makna bagi Korban Bencana di Indonesia
}

\author{
${ }^{1}$ Johannis Siahaya, ${ }^{2}$ Karel Martinus Siahaya, ${ }^{3}$ Nunuk Rinukti \\ 1,2,3Sekolah Tinggi Agama Kristen Teruna Bhakti, Yogyakarta \\ ${ }^{1}$ charistajasmine@gmail.com, 2karelsiahaya@yahoo.co.id,3nrsiahaya65@gmail.com
}

\begin{tabular}{|c|c|}
\hline \multirow[b]{2}{*}{$\begin{array}{l}\text { Article History } \\
\text { Submitted: } \\
\text { 12 February } 2020 \\
\text { Revised: } \\
\text { 20 March } 2020 \\
\text { Accepted: } \\
26 \text { March } 2020\end{array}$} & \multirow{3}{*}{$\begin{array}{l}\text { Abstract: The phenomenon of natural disasters has been felt in recent years and } \\
\text { has become a global concern. This concern occurs because, the intensity of } \\
\text { natural disasters that are increasingly frequent in various parts of the world } \\
\text { lately, taking many victims both human, property, and other lives. Religions } \\
\text { (including the church), however, have an essential calling and responsibility in } \\
\text { dealing with the problem of the victims of the disaster. However, today's reality } \\
\text { shows that religions (as well as internal church) are still involved and strug- } \\
\text { gling in classical debates about teachings (dogma) about who God is: about his } \\
\text { name, which God or religion is true, or what God teaches in which religion or } \\
\text { church which is considered correct. }\end{array}$} \\
\hline & \\
\hline & \\
\hline $\begin{array}{l}\text { functionaliz, } \\
\text { disaster reli }\end{array}$ & \\
\hline $\begin{array}{l}\text { natural disasters; } \\
\text { religion }\end{array}$ & $\begin{array}{l}\text { Abstrak: Fenomena bencana alam sangat terasa dalam beberapa tahun terakhir } \\
\text { sampai-sampai menjadi perhatian dunia. Hal ini terjadi karena, intensitas benca- }\end{array}$ \\
\hline $\begin{array}{l}\text { agama; } \\
\text { bencana alam; } \\
\text { bantuan bencana; } \\
\text { fungsionalisasi } \\
\text { gereja }\end{array}$ & $\begin{array}{l}\text { na alam yang semakin sering terjadi di berbagai belahan dunia termasuk di } \\
\text { Indonesia akhir-akhir ini, bahkan mengakibatkan banyak korban yang berja- } \\
\text { tuhan, selain kehilangan harta benda. Melihat fenomena ini gereja memiliki } \\
\text { panggilan dan tanggung jawab yang hakiki dalam dalam menangani korban } \\
\text { bencana tersebut. Namun, realitas yang terjadi adalah Agama-agama lain } \\
\text { bahkan gereja masih saja terlibat dalam berbagai perdebatan mengenai siapa }\end{array}$ \\
\hline & $\begin{array}{l}\text { Tuhan itu, mengenai nama-Nya, Agama mana yang benar, ataupun ajaran } \\
\text { Tuhan dari agama atau gereja mana yang dianggap benar. }\end{array}$ \\
\hline
\end{tabular}

\section{Pendahuluan}

Umat manusia dewasa ini diperhadapkan dengan berbagai realitas bencana alam di berbagai penjuru dunia, tak terkecuali di Indonesia. Bencana alam yang sangat sering terjadi seperti: gempa bumi, letusan gunung berapi, tsunami, banjir bandang, tanah longsor, angin topan, hingga pada anomali cuaca yang ekstrim. Memang, fenomena bencana alam ini sudah terjadi sejak masa lampau, bahkan dapat dikatakan sejak bumi ini mulai terbentuk. Sejarah mencatat, pernah terjadi beberapa kejadian (bencana) alam yang sangat memengaruhi umat manusia, seperti hancurnya beberapa peradaban dunia yang pernah ada, naiknya permukaan air laut, naiknya suhu bumi, dan berbagai dampak lainnya yang mempengaruhi kehidupan di dunia ini. Berbagai fenomena bencana alam yang terjadi itu telah mengakibatkan keprihatinan dunia. Keprihatinan ini terjadi karena, intensitas bencana alam yang semakin sering di berbagai belahan dunia akhir-akhir ini.

Peran media masa dalam mengekspos dan menyebarkan peristiwa-peristiwa bencana alam telah mempercepat pengetahuan khalayak umum di seluruh penjuru dunia. Selain itu, 
berbagai pertanyaan pun muncul terkait peristiwa tersebut; pertanyaan tentang mengapa peristiwa-peristiwa tersebut masih juga terjadi, bahkan menimpa hidup orang yang percaya kepada Tuhan. Pertanyaan tentang esensi bencana pun diajukan; apakah itu bentuk hukuman Tuhan? Namun, mengapa ada orang percaya yang juga terkena oleh berbagai bencana jika itu sebuah indikasi hukuman Tuhan?

Penelitian tentang bencana lebih banyak bersifat penanganan dari keilmuan lain, seperti penelitian yang dilakukan oleh Dradjat Suhardjo tentang pentingnya mitigasi bencana demi mengurangi risiko bencana. ${ }^{1} \mathrm{Hal}$ ini penting untuk dilakukan karena risiko dari bencana tidak dapat diduga dan sangat merugikan. Berbeda dengan Suhardjo, A. Rusilowati melakukan penelitian mitigasi bencana dalam kaitannya dengan pengembangan materi pembelajaran IPA di sekolah. ${ }^{2}$ Pada kedua penelitian tersebut menekankan penangangan terhadap orang yang terdampak oleh bencana alam. Karena memang harus disadari bahwa bencana yang kerap terjadi mengakibatkan kerusakan, dan untuk meminimalisirnya perlu penangan secara dini.

Selain itu, bencana yang terjadi juga kerap mengakibatkan trauma, sehingga tidak kalah penting untuk menangani korban akibat bencana ini secara psikologis, terutama trauma. ${ }^{3}$ Trauma akbita peristiwa bencana membutuhkan penanganan khusus dan waktu yang tidak cepat. Kembali kepada pentingnya tindakan meminimalisir risiko akbiat bencana, penelitian oleh Aldila Rahma mencoba menawarkan penerapan program untuk itu. ${ }^{4}$ Semua keadaan di atas menggambarkan adanya akibat yang sangat merugikan atas terjadinya bencana alam. Penanganan-penangan pun harus dilakukan demi memulihkan keadaan, baik secara fisik, kondisi sekitar maupun setiap orang yang terdampak olehnya.

Penanganan kesadaran pentingnya memelihara alam sepertinya tidak dapat diabaikan dalam konteks meminimalisir akibat bencana. Tidak jarang bencana yang terjadi karena akibat kesalahan manusia dalam menangani lingkungannya. Itu sebabnya penelitian tentang memperlakukan alam semesta atau lingkungan dalam konteks iman Kristen menjadi hal yang penting untuk diterapkan dalam masyarakat agamis, terutama masyarakat gereja. ${ }^{5}$ Kesadaran untuk membangun masyarakat yang mencintai lingkungan dan memelihara serta menjaganya merupakan bagian dari sebuah refleksi iman, khususnya kekristenan.

Bukan hanya dalam konteks iman Kristen, bencana yang terjadi juga dipandang dalam sebuah kacamata teologis agama lain, seperti Islam. ${ }^{6}$ Artinya, ada semacam kesadaran atau refleksi keagamaan bahwa apa yang terjadi di semesta tidak lepas dari peran ilahi. Bukan hanya dalam kacamata Islam, kekirstenan pun memahami segala kejadian termasuk bencana

\footnotetext{
${ }^{1}$ Dradjat Suhardjo, “Arti Penting Pendidikan Mitigasi Bencana Dalam Mengurangi Resiko Bencana,” Jurnal Cakrawala Pendidikan, no. 2 (2015): 174-188.

${ }^{2}$ A Rusilowati and A Binadja, "Mitigasi Bencana Alam Berbasis Pembelajaran Bervisi Science Environment Technology and Society,” Jurnal Pendidikan Fisika Indonesia 8, no. 1 (2012): 51-60.

${ }^{3}$ Endah Nawangsih, "Play Therapy Untuk Anak-Anak Korban Bencana Alam Yang Mengalami Trauma (Post Traumatic Stress Disorder/PTSD)," Psympathic : Jurnal Ilmiah Psikologi 1, no. 2 (2016): 164-178.

${ }^{4}$ Aldila Rahma, "Implementasi Program Pengurangan Risiko Bencana(PRB) Melalui Pendidikan Formal," Jurnal Varia Pendidikan 30, no. 1 (2018): 1-11.

${ }^{5}$ Kalis Stevanus, "Pelestarian Alam Sebagai Perwujudan Mandat Pembangunan: Suatu Kajian EtisTeologis," KURIOS: Jurnal Teologi dan Pendidikan Agama Kristen 5, no. 2 (2019): 94-108, http://www.sttpb.ac.id/e-journal/index.php/kurios/article/view/107/70.

${ }^{6}$ Abdul Mustaqim and A Pendahuluan, "Teologi Bencana Dalam Perspektif Al-Qur'an," Nun: Jurnal Studi Alquran dan Tafsir di Nusantara 1, no. 1 (2015): 91-109, http://ejournal.aiat.or.id/index.php/nun/article/view/9.
} 
dalam konteks iman Kristen. ${ }^{7}$ Di sinilah sebuah titik temu terlihat sepintas, bahwa ada keterkaitan antara benca alam dengan persoalan iman. Hanya saja cara memahaminya yang akan berbeda-beda karena kerangka imannya juga dalam konsep yang berbeda. Hanya saja kesadaran bahwa Tuhan tetap ada di balik bencana alam sekalipun harus dimaknai secara praksis sehingga menghasilkan refleksi iman yang seimbang dan dewasa. Refleksi iman yang dewasa ini sangat dibutuhkan dalam menghadapi segala keadaan termasuk bencana alam.

\section{Metodologi Penelitian}

Penelitian ini merupakan penelitian kualitatif literatur dengan menggunakan metode analisis deskriptif. Deskripsi tentang berbagai bencana yang terjadi, khususnya di Indonesia, menghadirkan ruang diskusi dan analisis reflektif secara sosio-religius dan teologis demi menghadirkan pemahaman tentang eksistensi Sang Ilahi, yaitu Tuhan Sang Pencipta di balik semua peristiwa tersebut. Proses dan makna (perspektif subyek) lebih ditonjolkan dalam penelitian ini. Penelitian Kualitatif bertolak dari data, memanfaatkan teori yang ada sebagai bahan penjelasan dan berakhir dengan suatu teori. Beberapa hal perlu dideskripsikan sebagai data faktual yang dianalisis terkait penelitian dalam artikel ini sebagai variabel.

\section{Korban Bencana}

Bencana alam dalam berbagai bentuk, seperti: letusan gunung merapi, tsunami, banjir, tanah longsor, badai, yang terjadi di berbagai penjuru dunia termasuk di Indonesia, telah menimbulkan berbagai dampak yang merusak dan menghancurkan (destruktif). Dampak itu dapat terjadi pada lingkungan atau alam, termasuk hewan dan tumbuhan, harta benda (material), bahkan manusia yang mengakibatkan kematian atau cacat. Bencana alam umumnya menimbulkan dampak fisik maupun psikis di antara mereka yang mengalaminya Tidak sedikit bencana yang sudah lama terjadi masih menyisahkan dampak psikologis seperti traumatik. ${ }^{8}$ Semua yang terdampak bencana alam harus mendapatkan penanganan secara holistik, sehingga dapat mengalami pemulihan.

Ketika bencana terjadi, mereka yang menjadi korban bencana membutuhkan keterlibatan dan bantuan berbagai berbagai pihak untuk menolong mereka, baik dalam bantuan fisik material, maupun bantuan-bantuan pendampingan bagi pemulihan psikis mereka. Perlu adanya kesadaran bahwa manusia yang menjadi korban bencana alam ini, tidak berasal dari kelompok, suku, etnis, ataupun agama tertentu saja. Demikian juga ketika bencana datang, ia tidak pernah memilih kelompok sasaran tertantu, siapa pun manusianya, karena apa pun benda atau makhluk lain yang dilalui oleh bencana akan mengalami akibat destruktifnya. Ketika bencana datang, setiap orang, bahkan yang menyatakan diri percaya kepada Allah Yang Mahakuasa, dan yang baik hati sekalipun, tidak dapat menghindarinya. ${ }^{9}$ Dalam masalah ini, muncul pertanyaan tentang 'teodisea'; jika ada Tuhan, mengapa ada bencana atau pende-

\footnotetext{
${ }^{7}$ Enggar Objantoro, “Bencana Alam Ditinjau Dari Perspektif Teologi Alkitab,” Jurnal Simpson: Jurnal Teologi dan Pendidikan Agama Kristen 1, no. 2 (2016): 131-150.

${ }^{8}$ Nawangsih, "Play Therapy Untuk Anak-Anak Korban Bencana Alam Yang Mengalami Trauma (Post Traumatic Stress Disorder/PTSD)."

${ }^{9}$ Franz Magnis Suseno, Menalar Tuhan (Yogyakarta: Kanisius, 2006).
} 
ritaan. Pertanyaan yang mewarnai sejarah umat manusia sejak dulu hingga dewasa ini, baik sebagai pertanyaan filsafat maupun pertanyaan teologis, yang masih terus dibahas.

\section{Pembahasan}

\section{Tuhan dalam Dogma Agama}

Pendeitaan dan bencana merupakan bagian dari kehidupan yang bisa menimpa siapa saja. Salah satu contoh kasus bencana alam yang berhubungan langsung dengan bangsa ini adalah yang pernah terjadi di wilayah Yogyakarta, yakni peristiwa erupsi gunung Merapi pada bulan Oktober 2010 yang lalu. Dalam peristiwa yang terjadi di Yogayakarta tersebut, tidak sedikit kerugian yang ditimbulkan, baik rumah, sawah dan ladang, hewan, dan sebagainya, tak terkecuali manusia. Jumlah korban jiwa yang meninggal saat itu, tercatat sebanyak 277 orang. ${ }^{10}$ Sedangkan data dari Badan Nasional Penanggulangan Bencana (BNPB), para pengungsi mencapai 235.858 yang tersebar di 735 titik pengungsian. Dari jumlah para pengungsi tersebut, 5\% di antaranya atau sebanyak 11.792 jiwa para pengungsi merapi tersebut mengalami gangguan jiwa pada saat kejadian. ${ }^{11}$ Ketika penanganan pasca-erupsi berlangsung selama dua bulan, masih terdapat sebanyak 756 orang mengalami gangguan jiwa, 52 di antaranya gangguan jiwa berat dan harus dirawat di rumah sakit jiwa. ${ }^{12}$ Ini hanyalah salah satu contoh kasus dari begitu banyaknya kasus bencana yang terjadi di Indonesia, seperti peristiwa Tsunami yang melanda Aceh dan beberapa tempat di Indonesia, dan gempa di Palu beberapa waktu lalu.

Para korban bencana alam merupakan orang-orang yang berada dalam penderitaan dan sangat membutuhkan bantuan, baik material maupun berbagai bentuk pendampingan dan penguatan. Berbagai bencana yang terjadi di bangsa ini tidak lalu membiarkan agama apa pun termasuk termasuk orang Kristen hanya berdiam diri saja. Gereja, sejatinya, memiliki panggilan dan tanggung jawab yang hakiki dalam menangani persoalan korban bencana tersebut. Namun, realitas dewasa ini memperlihatkan bahwa agama-agama (juga internal gereja) masih banhyak yang terlibat dan berkutat dalam perdebatan klasik mengenai ajaran (dogma). Pertentangan tentang siapa Tuhan; mengenai nama-Nya, Tuhan agama atau gereja mana yang benar, ataupun ajaran Tuhan pada agama atau gereja mana yang dianggap benar. Dalam berbagai perdebatan ini, agama-agama termasuk gereja sering melupakan dan mengabaikan aspek penting dari hakikat agama yakni membawa kebaikan dan karya penyelamatan bagi umat manusia, bukan berkutat dalam perdebatan-perdebatan dogmatis tersebut.

Agama-agama (dan gereja) sering melupakan dimensi dialog praksis (karya) dari agama dan lebih mengutamakan dimensi dialog dogmatis (ajaran) di antara agama-agama. Agamaagama (termasuk gereja) juga masih sering terjebak dalam paradigma institusional, yang melihat fungsi agama secara introvert pada aspek-aspek fisik dan ritual keagamaan. Agama sering menekankan pembangunan fisik fasilitas-fasilitas pendukungnya, tempat-tempat ibadah (masjid, gereja, kuil, pura) yang sangat megah, terutama di Indonesia. Demikian juga dengan praktik ritual keagamaan yang marak di Indonesia, seringkali menguras energi sosial dan

\footnotetext{
${ }^{10}$ Semua data tentang ini dapat diakses pada situs resmi pemerintah kabupaten Sleman, www.slemankab.go.id

${ }^{11}$ www.kompas.com, diakses: 20 November 2010

${ }^{12}$ Data dari Dinas Kesehatan Sleman yang diakses pada www.kompas.com, pada 29 Desember 2010
} 
negara habis tersita bagi perayaan ritual-ritual keagamaan tersebut. Demikian juga dengan gereja-gereja, terjebak dalam orientasi fisik tersebut, di mana-mana didirikan bangunan gereja yang megah dengan beban anggaran yang tidak sedikit. ${ }^{13}$ Fenomena megachurch telah menjadi trend di kota besar, dan tidak sedikit menuai kritik karena cenderung berorientasi pada gengsi pribadi dan organisasi.

Pada sisi lain, acara-acara ritual gerejawi sering dijadikan ukuran eksistensi suatu gereja, sehingga gereja berlomba melakukan ritual yang megah, terutama acara-acara kebangunan rohani di mal-mal, stadion maupun di lapangan-lapangan terbuka yang memperlihatkan kemarakan dan kekuatan gereja tersebut kepada publik. Bukan bermaksud untuk negative thinking terhadap keadaan ini, tetapi perlu dipertanyakan apakah hal tersebut menjadi panggilan gereja yang hakiki ${ }^{14}$, sehingga sebagian besar energi gereja harus terkuras bagi aspek fisik-ritual tersebut? apakah aspek ini menjadi hakikat kehadiran gereja di dunia sebagaimana dikehendaki Tuhan?

Setiap agama memaknai Tuhan dan kehendak-Nya secara berbeda menurut pandangan dan pemahamannya masing-masing. Tiap agama menekankan aspek-aspek yang berbeda dari Tuhan yang Esa tersebut. Demikian juga di dalam kekristenan, masing-masing gereja menekankan aspek-aspek tertentu dari Yesus yang satu yang telah diyakini sebagai Tuhan dan Juruselamat dunia. Pada titik ini, dapat dilihat bagaimana Tuhan yang Esa dan Satu tersebut dipahami dan dimaknai secara berbeda oleh masing-masing agama, termasuk oleh masingmasing gereja. Bahkan demi mempertahankan keyakinannya tersebut, ada orang yang rela mati untuk membela keyakinannya tentang Tuhan. Hal ini patut dipertanyakan, agama (termasuk gereja) yang harus memperlihatkan sisi damai dan kebaikan bagi dunia, ternyata memperlihatkan sisi kekerasan dan keburukan di tengah-tengah dunia. Agama (dan gereja) tidak hadir sebagai penyelesai masalah (problem solving) tetapi sebagai pembuat masalah (problem making) bagi umat manusia dan dunia, justru ketika terjebak pada pemahaman tentang Tuhan secara introvert tersebut. Apakah Tuhan mesti dimaknai sedemikian dengan berbagai dampak destruktif yang ditimbulkannya?

\section{Fungsionalisasi Agama dan Tuhan bagi Manusia}

Menyikapi fenomena ini, menarik untuk disimak apa yang ditegaskan oleh Karen Armstrong, bahwa Tuhan tiga agama Abrahamik (Yahudi, Kristen, Islam) adalah Tuhan yang-dalam beberapa pengertian-berkata-kata (berfirman). Armstrong mengatakan bahwa FirmanNya sangat krusial di dalam ketiga agama besar itu. ${ }^{15}$ Firman Tuhan ini telah membentuk sejarah kebudayaan manusia. Hal itu berarti bahwa agama-agama dimaksud, bagaimanapun memahami Tuhan sebagaimana Ia berkata-kata (berfirman) di dalam kitab suci agama masingmasing. Pemahaman terhadap Firman Tuhan dalam masing-masing kitab suci itulah yang mengarahkan eksistensi dan karya setiap agama di dalam sejarah umat manusia, sekaligus ikut menciptakan peradaban umat manusia. Sehubungan dengan itu, Will Herberg menegas-

\footnotetext{
${ }^{13}$ Y M Imanuel Sukardi, “Gereja Ekstra Biblikal Dan Tanggung Jawab Dalam Menyelesaikan Amanat Agung," KHARISMATA: Jurnal Teologi Pantekosta 1, no. 2 (2019): 37-39, http://www.ejournal.stajember.ac.id/index.php/kharismata/article/view/22.

${ }^{14}$ Ibid.

${ }^{15}$ Karen Armstrong, A History of God (Sejarah Tuhan: Kisah 4.000 Tahun Pencarian Tuhan Dalam AgamaAgama Manusia) (Bandung: Mizan Pustaka, 2001).
} 
kan bahwa Tuhan agama Yahudi adalah Tuhan Bibel, yaitu Tuhan yang hidup (The Living God). Sedangkan dalam Islam yang merupakan gabungan rangkaian terakhir yang didahului oleh agama Yahudi dan Nasrani, sifat personality Tuhan sangat terang. ${ }^{16}$ Sejarah pun mencatat bahwa agama bisa menjadi alat perdamaian dan membawa kebaikan bagi umat manusia, tetapi agama pun sering menjadi alat kekerasan dan membawa kehancuran bagi umat manusia.

Agama, bagaimanapun hadir di dunia bagi kebaikan (kemaslahatan) umat manusia. Ia turut mendorong terciptanya peradaban umat manusia yang semakin berkualitas dari waktu ke waktu. Agama mendorong terciptanya peradaban yang egaliter, humanis, demokratis, sejahtera, berkeadilan, dan sebagainya. Hal ini hanya bisa terwujud jika agama-agama mau melihat dan memaknai Tuhan dan FirmanNya (kehendakNya) tidak semata-mata pada aspek ritual semata tetapi terwujud nyata dalam aspek sosial umat manusia. Agama ketika memaknai Tuhan yang esa dan satu tersebut, mesti keluar dari rumah ritualnya dan berkarya dalam lapangan sosial bagi kemajuan peradaban umat manusia tersebut. Sehubungan dengan hal dimaksud Armstrong mengingatkan bahwa Tuhan dalam agama, khususnya Yahudi, Kristen dan Islam, telah mengilhami cita-cita keadilan sosial. ${ }^{17}$ Hal itu tidak terabaikan meskipun harus dikatakan bahwa orang Yahudi, Kristen, dan muslim sering gagal meraih cita-cita ini dan bahkan telah mentransformasinya menjadi Tuhan status quo. Kehendak Tuhan yang diajarkan oleh semua agama untuk mewujudkan keadilan sosial tersebut, mengharuskan agama-agama untuk mewujudkan cita-cita dimaksud bukanlah dengan saling berspekulasi dan memperdebatkan ajaran (dogma) tentang siapa yang benar, tetapi melalui karya nyata bagaimana menjadikan dirinya dan kehendak Tuhan yang diajarkannya tersebut dapat fungsional dalam masyarakat, demi kebaikan dan meningkatkan kualitas peradaban umat manusia. Karena itu, menegaskan kembali ide Armstrong, bahwa agama adalah disiplin amaliah, dan wawasannya tidak berasal dari spekulasi abstrak, tetapi dari latihan spiritual dan gaya hidup yang berdedikasi.

Bagaimana memahami dan menggambarkan tentang Tuhan yang masih terus diperdebatkan tersebut? Menggambarkan Tuhan dalam arti apa saja yang dibayangkan dan dipikirkan tentang Allah, dan yang dikira berlaku sebagai pernyataan yang benar mengenai Tuhan tersebut. Pengertian tentang Tuhan pada setiap agama bahkan pada tiap orang berbeda-beda, sesuai dengan gambaran tentang Tuhan yang diterima dalam setiap agama maupun tiap orang. Huijbers menjelaskan bahwa secara global manusia menggambarkan Tuhan (Allah) dalam tiga bentuk. ${ }^{18}$ Pertama, sebagai gambar yang riil, yakni Allah sebagaimana Ia dihayati dalam hati setiap orang. Isinya tergantung dari pengalaman tiap orang masing-masing. Gambaran Allah semacam ini adalah beraneka warna, juga pada orang-orang yang menganut satu agama. Kedua, gambaran yang ideal dalam agama, yakni Allah sebagaimana diwartakan dalam ajaran resmi salah satu agama. Di sini pengertian tentang Allah tidak seragam, tiap agama membawa pandangannya sendiri. Ketiga, gambaran yang ditemukan pada sistem filsafat, yakni Allah

\footnotetext{
${ }^{16}$ David Trueblood, Philosophy of Religion (Jakarta: Bulan-Bintang, 1965).

${ }^{17}$ Armstrong, A History of God (Sejarah Tuhan: Kisah 4.000 Tahun Pencarian Tuhan Dalam Agama-Agama Manusia).

${ }^{18}$ Theo Huijbers, Mencari Allah: Pengantar Ke Dalam Filsafat Ke-Tuhan-An (Yogyakarta: Kanisius, 1992).
} 
sebagaiman dipikirkan hakikat-Nya oleh para filsuf. Seperti gambaran agama, gambaran ini juga bersifat ideal, dan tentang isinya tidak ada kesepakatan juga. Penjelasan Huijbers ini meyadarkan kita bahwa Tuhan tersebut tidak dapat dipahami dengan suatu metode tunggal, tidak ada satupun metode yang mampu menjelaskan Tuhan secara sempurna. Karena itu, Tuhan yang maha besar tersebut, bagaimana pun tidak dapat ditangkap oleh metode manusiawi, dan perdebatan tentang hal ini tidak lain merupakan pekerjaan menjaring angin.

Tuhan yang diajarkan oleh agama-agama ini juga menjadi pergumulan dalam ranah filsafat. Kebenaran ideal tentang Tuhan yang digambarkan oleh agama, diterima oleh para penganutnya melalui keyakinan dengan iman, sedangkan yang digambarkan oleh sistem filsafat bersifat rasional, akan diterima sebagai kebenaran bila dapat dijelaskan dan diterima secara logis. Karena itu, dikenal istilah 'Tuhan para filsuf dan ilmuwan' yang dipopulerkan oleh Blaise Pascal ${ }^{19}$, Tuhan yang coba dikenal, dipahami dan dijelaskan oleh para filsuf dan ilmuwan. Konsepsi tentang Tuhan dan eksistensinya telah menjadi perdebatan yang berkepanjangan, baik dalam ranah teologi maupun filosofi. Pada ranah teologi (agama), ada yang memahami Tuhan bersifat transenden yakni Tuhan yang jauh di luar manusia dan alam ini dan tidak bisa diserupakan dengan apapun di dunia ini, ada yang menganggapNya bersifat imanen yakni Tuhan yang berada di dalam alam dan dapat ditemui oleh manusia, ada yang menganggapNya bersifat panteistis yakni segala sesuatu adalah Tuhan, dan seterusnya.

Dalam ranah filsafat-pun, perdebatan tentang Tuhan menjadi salah satu tema utama dalam filsafat agama. Dalam perdebatan filsofis yang berkepanjangan tentang Tuhan tersebut, menarik untuk kita menyimak pendapat seorang filsuf Jerman, Georg Hegel yang mengartikan Tuhan sebagai Allah yang hidup dan aktif terlibatdi dalam dunia. Hegel menolak segala macam pandangan mengenai Allah dari para pemikir sebelumnya: Allah yang melulu konstruksi rasional (Descartes), Allah sebagai Ide regulatif dan postulat moral (Kant), Allah sebagai "Tukang pembuat arloji" yang tidak berurusan lagi dengan ciptaan-Nya setelah menciptakannya (Deisme), atau Allah sebagai objek nonrasional atau perasaan (Pascal dan Schleiermacher). Sebaliknya, Allah yang diajarkan Hegel adalah Allah di dalam dunia, Yang Transenden di dalam Yang Imanen, Yang Surgawi di dalam Yang Duniawi, Yang Kekal di dalam Yang Fana. Filsafat Hegel ini bersifat agamawi dan agamanya bersifat filosofis. ${ }^{20}$

Sampai pada titik ini, kiranya pembahasan di atas dapat dipahami, bahwa perdebatan tentang Tuhan secara dogmatis tidaklah berarti bagi kebaikan dan kemajuan peradaban umat manusia dan dunia. Hakikat eksistensi agama di dunia mesti bertumpu pada tanggung jawabnya untuk bagaimana mengfungsikan dirinya dan kehendak Tuhan yang diajarkannya bagi kebaikan dan kemajuan manusia tersebut. Karena itu, teringat tentang pernyataan mantan presiden RI Abdulrachman Wahid (Gus Dur), bahwa "Tuhan tidak perlu dibela". ${ }^{21}$ (2010). Tuhan memang tidak perlu dibela jika manusia mengakui Ia sebagai yang Maha Kuasa. Justru agama-agama mesti berkarya untuk mewujudkan kehendak Tuhan yang berkuasa tersebut untuk kebaikan dunia, terutama terhadap mereka yang mengalami bencana.

\footnotetext{
${ }^{19}$ Simon Petrus L Tjahjadi, Tuhan Para Filsuf Dan Ilmuwan (Yogyakarta: Kanisius, 2007).

${ }^{20}$ Ibid. 88 .

${ }^{21}$ Abdurrahman Wahid, Tuhan Tidak Perlu Dibela (Yogyakarta: LKIS, 2010).
} 


\section{Reinterpretasi Tuhan melalui pengalaman korban bencana}

Debat tentang Tuhan bukanlah sebuah agenda prioritas bagi peradaban manusia dewasa ini. Dialog (perdebatan) dogmatis mengenai Tuhan yang sering mewarnai sejarah agama-agama (termasuk gereja) semestinya digantikan dengan dialog karya yang fungsional bagi kemajuan peradaban manusia, khususnya di tengah-tengah kehidupan global yang sering diwarnai bencana alam dewasa ini. Tuhan yang selama ini menjadi perdebatan yang spekulatif semestinya difungsikan sebagai Tuhan yang berkarya melalui para pengikutnya untuk menciptakan keadilan sosial dan kesejahteraan umat manusia di tengah-tengah berbagai penderitaan umat manusia akibat bencana alam dewasa ini. Tuhan bukanlah subjek yang terus diperdebatkan dalam interpretasi-interpretasi teologis maupun filosofis yang bersifat spekulatif, tetapi Tuhan yang kehendak-kehendakNya difirmankan dalam kitab suci masingmasing agama mesti direinterpretasikan sebagai Tuhan yang fungsional, Tuhan yang mengalami, terlibat dan mengangkat manusia dari berbagai penderitaan di dunia.

Reinterpretasi agama-agama dari Tuhan yang dikonsepkan dalam dogma agama menjadi Tuhan yang berkarya bagi kemanusiaan ini, didorong oleh realitas umat manusia yang terus mengalami penderitaan dan memerlukan kontribusi nyata dari agama-agama. Bagaimana pun, para korban bencana alam bukan hanya memerlukan konsep tentang Tuhan yang "idealis" yang hanya merupakan dogma agama-agama semata, tetapi Tuhan yang realis yang hadir di tengah-tengah kesusahan tersebut. Dengan kata lain, manusia khususnya para korban bencana tidak hanya memerlukan kehadiran Tuhan yang maha kuasa yang bersifat transenden semata, tetapi lebih dari pada itu, para korban bencana ingin melihat kehadiran Tuhan yang maha kuasa yang bersifat imanen, yang hadir dan menolong umat manusia di tengah-tengah penderitaannya melalui kehadiran gereja secara nyata di tengah-tengah para korban bencana tersebut.

Pengalaman para korban bencana yang mengalami penderitaan baik fisik maupun psikis semestinya menyadarkan agama-agama termasuk gereja untuk menghadirkan Tuhan yang fungsional melalui karya nyata mereka bagi penanggulangan para korban bencana dimaksud. Karena itu, tidak salah bagi agama-agam untuk memperhatikan tantangan John Capito dalam bukunya: "agama cinta, agama masa depan" (2001). Masa depan peradaban manusia adalah masa depan yang mengharapkan fungsi agama yang selalu mengkaryakan cinta kasih bagi umat manusia, bukan berbagai bentuk destruktif dan profokatif yang memperburuk wajah peradaban.

\section{Gerakan Bantuan Bencana: Refleksi Memaknai Tuhan di dalam Kekristenan}

Tak bisa dipungkiri bahwa peristiwa bencana alam dan para korban yang ditimbulkannya telah mendapat perhatian dari gereja-gereja di Indonesia dewasa ini. Adanya Yayasan Tanggul Bencana di tingkat Persekutuan Gereja-gereja di Indonesia maupun komisi-komisi penanggulangan bencana di tingkat Sinode masing-masing Gereja menjelaskan tanggung jawab dimaksud.Memang, realitas bencana alam yang sering melanda Indonesia dewasa ini mendorong gereja-gereja untuk meninggalkan perdebatan-perdebatan dogmatis dan tata-cara ritual yang hendak mengunggulkan satu gereja atas gereja lain, serta menjadikanbencana alam sebagai konteks berteologi bersama, mendorong gereja-gereja untuk merapatkan persekutuan dan bersama-sama menjadikannya sebagai dialog karya yang fungsional bagi kemanusiaan. 
Diperhadapkan dengan konteks dan realitas bangsa Indonesia yang rawan bencana karena letaknya pada zona ring of fire mengharuskan gereja melakukan reinterpretasi terhadap eksistensinya, bukan lagi semata-mata hanya bagi dirinya sehingga bersifat introvert dan menghabiskan energi untuk aspek institusional baik fisik maupun ritual, tetapi menjadikan dirinya berkarya bagi kebaikan umat manusia sebagaimana yang dikehendaki Allah di dalam Yesus Kristus.

Panggilan dan keterlibatan gereja terhadap persoalan bencana alam dengan para korbannya, tidak lain merupakan hakikat dari eksistensi gereja di dunia khususnya di Indonesia. Allah yang diyakini di dalam kekristenan sebagai yang transenden tetapi juga yang imanen di dalam kehadiran Yesus Kristus di dunia. Yesus diyakini oleh gereja sebagai Tuhan dan Juruselamat dunia. Keyakinan kekristenan mensyaratkan Tuhan yang diimani adalah Tuhan yang juga antropos dan personal, yang hadir sebagai dan di tengah-tengah kehidupan manusia. Tuhan dalam kekristenan adalah Tuhanyang hadir dan ikut merasakan penderitaan manusia, sekaligus yang berusaha mengatasi persoalan-persoalan kemanusiaan tersebut. Alkitab sebagai kitab suci dan Firman Tuhan bagi kekristenan dengan sangat jelas memperlihatkan kisah-kisah tentang Tuhan yang hadir dan ikut mengalami penderitaan manusia. Beberapa kisah dalam alkitab dapat disinggung di sini.

Narasi tentang Abraham yang bertemu dengan tiga orang di dekat pohon tarbantin di Mamre dalam Kejadian 18, di mana salah satunya adalah Tuhan yang menampakkan diri kepada Abraham dan mengulangi janji-Nya bagi Abraham dan Sarah untuk mendapatkan anak (Ishak) di tahun berikutnya. Dalam peristiwa teofani ini, Tuhan menyerupai manusia dan bertemu langsung dengan manusia yang bernama Abraham tersebut. Demikian juga dengan narasi Yakub yang bertemu dan bergulat dengan Tuhan di Betel (Kej. 28:10-22), serta berbagai narasi lainnya. Benang merah dari narasi-narasi dimaksud menjelaskan Tuhan tampak secara antropos dan personal hadir dan bertemu dengan kehidupan manusia. Tuhan Allah di dalam kekristenan bukanlah sebagai "Tukang pembuat arloji" yang setelah menciptakan manusia dan dunia, lalu pergi meninggalkannya dan tidak lagi berurusan dengan ciptaan-Nya tersebut. Tuhan di dalam kekristenan adalah Allah tetap menyertai ciptaanNya dan menuntun serta mengarahkan manusia untuk menjalani kehidupan di dunia, serta yang menuntun manusia untuk mencari dan menemukan solusi terhadap berbagai persoalan dalam hidupnya.

Tuhan yang hadir dalam kekristenan itu juga adalah Allah di dalam Yesus yang turut menderita dan ikut merasakan di dunia ${ }^{22}$, dan lewat pengorbananNya di salib telah menyelamatkan manusia dari kuasa dosa dan penderitaan dunia. Karya pengorbanan dan pembebasan oleh Yesus bagi dunia ini juga menghendaki agar gerejaNya (umat) untuk ikut serta mengusahakan karya pengorbanan di maksud bagi seluruh umat manusia. Karya keselamatan yang dilakukan oleh Yesus tersebut bukanlah hanya untuk dinikmati oleh gereja-Nya, hanya menjadi milik gereja semata, tetapi mensyaratkan gereja untuk terus mewartakan dan mengatakan karya selamat tersebut kepada dunia sepanjang zaman. Karya selamat tersebut sebagaimana yang disampaikan Yesus dalam Lukas 4:18,19, ketika mengutip nubuatan nabi Yesaya:

\footnotetext{
${ }^{22}$ Elvin Atmaja Hidayat, "Iman Di Tengah Penderitaan: Suatu Inspirasi Teologis-Biblis Kristiani," Melintas: International Journal of Philosophy and Religion 32, no. 3 (2017): 285, http://journal.unpar.ac.id/index.php/melintas/article/view/2695.
} 
kabar baik kepada orang miskin, berita pembebasan kepada paratawanan, penglihatan bagi orang buta, membebaskan orang tertindas, serta memberitakan datangnya tahun rahmat Tuhan. Visi Yesus tentang Injil yang membebaskan ini menjadi hakikat keberadaan gereja di dunia. Gereja terpanggil dan memiliki tanggung jawab moral untuk maksud yang diamanatkan Yesus sebagai kepala gereja.

Gereja sebagai institusi keagamaan tidak hanya mengajarkan tentang Tuhan yang berkuasa menciptakan alam semesta termasuk manusia, tetapi menghadirkan kehendak Tuhan yang terus menghendaki kebaikan umat manusia dan dunia melalui karya-karya nyata, terutama bagi mereka yang menjadi korban bencana alam. Yesus menegaskan secara eksplisit dalam Matius 25:40: “...Aku berkata kepadamu, sesungguhnya segala sesuatu yang kamu lakukan untuk salah seorang saudara-Ku yang paling hina ini, kamu telah melakukannya untuk Aku." Dalam ayat 35 dan 36, Yesus mengidentifikasikan dirinya dengan orang yang lapar, haus, orang asing, telanjang, sakit, dan dipenjara. Jelas di sini bahwa di dalam Yesus, Tuhan Allah yang transenden menjadi imanen, antropos dan personal, mengalami penderitaan dan menghendaki para pengikutNya (gereja) untuk ikut menanggulangi dan memberdayakan mereka yang mengalami penderitaan. Singkatnya, menjadi pengikut Kristen adalah menjadi Kristus bagi orang lain, mewujudkan karya pembebasan Kristus bagi mereka yang mengalami penderitaan di dunia.

\section{Kesimpulan}

Di tengah-tengah penderitaan para korban bencana, gereja sebagai institusi agama terpanggil dan bertanggung jawab terhadap masalah penderitaan tersebut, bukan sebagai suatu gerakan sosial semata, tetapi sebagai gerakan iman. Gerakan bantuan bencana yang dilakukan oleh gereja bukanlah semata sebagai bentuk keprihatinan sosial, tetapi sebagai fungsionalisasi dan aktualisasi karya penyelamatan Tuhan bagi dunia yang telah dibuktikan Yesus di kayu salib, itulah hakikat eksistensi gereja di dunia khususnya di Indonesia. Gereja dalam realitas bangsa Indonesia yang rawan bencana alam mesti menampilkan dirinya sebagai gereja yang menghadirkan cinta kasih bagi mereka yang menderita dan bagi seisi dunia ciptaan Allah.

\section{Referensi}

Armstrong, Karen. A History of God (Sejarah Tuhan: Kisah 4.000 Tahun Pencarian Tuhan Dalam Agama-Agama Manusia). Bandung: Mizan Pustaka, 2001.

Hidayat, Elvin Atmaja. "Iman Di Tengah Penderitaan: Suatu Inspirasi Teologis-Biblis

Kristiani." Melintas: International Journal of Philosophy and Religion 32, no. 3 (2017):

285. http://journal.unpar.ac.id/index.php/melintas/article/view/2695.

Huijbers, Theo. Mencari Allah: Pengantar Ke Dalam Filsafat Ke-Tuhan-An. Yogyakarta: Kanisius, 1992.

Mustaqim, Abdul, and A Pendahuluan. "Teologi Bencana Dalam Perspektif Al-Qur'an.” Nun:

Jurnal Studi Alquran dan Tafsir di Nusantara 1, no. 1 (2015): 91-109.

http://ejournal.aiat.or.id/index.php/nun/article/view/9.

Nawangsih, Endah. "Play Therapy Untuk Anak-Anak Korban Bencana Alam Yang

Mengalami Trauma (Post Traumatic Stress Disorder/PTSD)." Psympathic : Jurnal

Ilmiah Psikologi 1, no. 2 (2016): 164-178.

Objantoro, Enggar. "Bencana Alam Ditinjau Dari Perspektif Teologi Alkitab.” Jurnal

Simpson: Jurnal Teologi dan Pendidikan Agama Kristen 1, no. 2 (2016): 131-150. 
Rahma, Aldila. "Implementasi Program Pengurangan Risiko Bencana(PRB) Melalui Pendidikan Formal." Jurnal Varia Pendidikan 30, no. 1 (2018): 1-11.

Rusilowati, A, and A Binadja. "Mitigasi Bencana Alam Berbasis Pembelajaran Bervisi Science Environment Technology and Society." Jurnal Pendidikan Fisika Indonesia 8, no. 1 (2012): 51-60.

Stevanus, Kalis. "Pelestarian Alam Sebagai Perwujudan Mandat Pembangunan: Suatu Kajian Etis-Teologis.” KURIOS: Jurnal Teologi dan Pendidikan Agama Kristen 5, no. 2 (2019): 94-108. http://www.sttpb.ac.id/e-journal/index.php/kurios/article/view/107/70.

Suhardjo, Dradjat. "Arti Penting Pendidikan Mitigasi Bencana Dalam Mengurangi Resiko Bencana.” Jurnal Cakrawala Pendidikan, no. 2 (2015): 174-188.

Sukardi, Y M Imanuel. "Gereja Ekstra Biblikal Dan Tanggung Jawab Dalam Menyelesaikan Amanat Agung.” KHARISMATA: Jurnal Teologi Pantekosta 1, no. 2 (2019): 37-39. http://www.e-journal.stajember.ac.id/index.php/kharismata/article/view/22.

Suseno, Franz Magnis. Menalar Tuhan. Yogyakarta: Kanisius, 2006.

Tjahjadi, Simon Petrus L. Tuhan Para Filsuf Dan Ilmuwan. Yogyakarta: Kanisius, 2007. Trueblood, David. Philosophy of Religion. Jakarta: Bulan-Bintang, 1965.

Wahid, Abdurrahman. Tuhan Tidak Perlu Dibela. Yogyakarta: LKIS, 2010. 